\title{
Berry quality of hybrid grapevine (Vitis) cultivars grown in the field and in a polytunnel
}

\author{
Mariana Maante-Kuljus, Ele Vool, Leila Mainla, Marge Starast and Kadri Karp \\ Department of Horticulture, Institute of Agricultural and Environmental Sciences, Estonian University of Life Sciences, \\ Fr. R. Kreutzwaldi 1a, EE51014 Tartu, Estonia \\ e-mail: mariana.maante-kuljus@emu.ee
}

\begin{abstract}
The aim of this research was to determine the effect of vineyard location and cultivation system (polytunnel compared to field) on hybrid grapevine berry quality in cold climate conditions. The study was conducted with the hybrid grapevine cultivars 'Hasanski Sladki', 'Zilga' and 'Supaga'. Experimental vineyards were located at different sites in a polytunnel and in the field. Soluble solids content ranged from 13.8 to $25.4^{\circ}$ Brix. For all cultivars cultivation in the tunnel had a positive effect on soluble solids content for two experimental years out of three. Acid

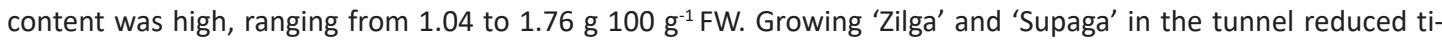
tratable acid content every year but for 'Hasanski Sladki' in two years. Phenolic content ranged from 53 to $540 \mathrm{~g}$ $100 \mathrm{~g}^{-1} \mathrm{FW}$ and anthocyanin from 30 to $162 \mathrm{mg} 100 \mathrm{~g}^{-1} \mathrm{FW}$. Accumulation of phenols and anthocyanins were affected by location and cultivation methods. For 'Hasanski Sladki' in the tunnel, cultivation had a positive effect on phenolic content but for 'Zilga' not in every year.
\end{abstract}

Key words: soluble solids, titratable acid, juice $\mathrm{pH}$, total anthocyanin, total phenolic

\section{Introduction}

In grapevine growing and wine making, work outcome depends on many different factors. French winemakers, who noticed differences in wines from different regions and vineyards, developed the concept of terroir which brings all factors together (Deloire et al. 2005, Edo-Roca et al. 2013, Tarricone et al. 2013). It involves interactions between cultivar, climate (macro-, meso-, topo- and microclimate), soil conditions (geology, pedology), vine water status, and human factors (viticultural practices) (van Leeuwen and Seguin 2006, Anesi 2015). According to Pereira et al. (2006), the grape metabolic profile is more affected by climatic characteristics (temperature and water balance) than soil conditions. The extent and timing of water stress is also important (Hunter and Deloire 2006). Increased anthocyanin concentration is related to fewer extreme temperature $\left(>35^{\circ} \mathrm{C}\right)$ days, lower vine water status and nitrogen level (Cheng et al. 2014).

In cold climate conditions, vine growers face several challenges: late spring and early autumn frosts, occasional cool summers, severe winters, and short growing seasons (Gustafsson and Mårtensson 2005). In traditional grapevine cultivation regions, the growing season is becoming warmer (Jones et al. 2005). Global warming is also observed in colder climate regions, such as Estonia: highly fluctuating winter temperatures and extreme weather conditions are more frequent; pests, diseases, and excess water are more abundant (Baseline report 2017). According to over ten years of monitoring in southernmost Finland, grape growing under existing weather conditions is possible (Karvonen 2014a). A study revealed that 'Zilga', crossbred in Latvia by Paul Sukatnieks, has acclimatized to Finnish growing conditions producing a soluble solids content of an average of $19^{\circ}$ Brix at harvest (Karvonen 2014b). In Sweden, mapping a sensor system for the Nordic Light Terroir character of wine has been developed in relation to climate change but retaining its fresh acidic/citrus nature (Nordmark et al. 2016). In Nordic countries, longer sunshine hours during the growing season can compensate for the shorter growing season and cooler summer. Cultivation of grapes in a polytunnel helps improve temperature conditions, enhancing earlier yield (Kamiloğlu et al. 2011). It can prolong the growing season, stimulate earlier vine bud break, and decrease vine injuries due to spring and autumn frosts. Cultivar selection is also important, and thus, Vitis vinifera and V. labrusca, V. riparia, V. rupestris, V. aestivalis (Lisek 2012), and V. amurensis (Gustafsson and Mårtensson 2005) hybrids are suitable for cold climate growing. Cultivation technologies (cane-girdling and cluster-berry thinning) can affect grape composition (Keskin et al. 2013). In Estonia, different techniques, such as pruning methods (Rätsep et al. 2014), defoliation (Maante et al. 2016), and cultivar effect on wine chemical composition (Pedastsaar et al. 2014) has been tested in the field. Technological maturity proved to be a problem because grape still had a high acid and a low sugar content. For phenolic maturity, which is important in red wine making, it was revealed that phenol and anthocyanin contents vary greatly. 
We can thus hypothesize that in a cold climate, growing interspecific hybrid grapevine cultivars in a polytunnel positively affects grape maturity. The aim of the study was to compare fruit technological and phenolic maturity parameters of the hybrid grape cultivars 'Hasanski Sladki', 'Zilga', and 'Supaga' grown in vineyards (in separate locations) with different cultivation systems (polytunnel and field).

\section{Material and methods}

\section{Experimental sites and plant material}

The experimental vineyards were established in 2007 with own-rooted plants of the hybrid wine grape cultivars: 'Hasanski Sladki' $(V$. amurensis $\times$ V. labrusca $\times$ V. riparia $\times V$. vinifera), 'Zilga' $(V$. amurensis $\times$ V. labrusca $\times$ $V$. vinifera) and 'Supaga' $(V$. vinifera $\times V$. labrusca). The experimental design was a randomized block with 4 replicates and 8 vines in each. In the field the $\left(58^{\circ} 21^{\prime} 27^{\prime \prime} \mathrm{N}, 26^{\circ} 31^{\prime} 16^{\prime \prime} \mathrm{E}\right)$ vines were planted in $2 \times 2 \mathrm{~m}$ spaces, trained on a low double trunk trellis, and spur pruned. The vines were not covered for winter. The polytunnel $\left(58^{\circ} 37^{\prime} 42^{\prime \prime}\right.$ $\mathrm{N}, 25^{\circ} 8^{\prime} 17^{\prime \prime} \mathrm{E}$ ) was $45 \mathrm{~m}$ long, $8 \mathrm{~m}$ in wide and $4 \mathrm{~m}$ in high. From the end of April until the beginning of November, the tunnel was covered with $0.18 \mathrm{~mm}$ thick UV stable low-density polyethylene. Vines were planted in $1.5 \times 3.5 \mathrm{~m}$ spaces along the tunnel walls, trained in high double trunk trellis, and cane pruned. The tunnel did not have a foundation and therefore plants could get moisture from outside the tunnel. White polypropylene fabric was used as winter cover. The distance between the experimental sites was ca. $86 \mathrm{~km}$. At both sites, the vine rows were oriented from north to south, the ground was covered with woven ground cover fabric and no additional irrigation was supplied. Leaves were removed from the cluster zone at the beginning of veraison (fruit coloration phase).

The soil in the field site was high-productivity sandy loam Haplic luvisol with sufficient drainage. That of the tunnel was a loam sandy Gleyic albeluvisol soil. Gleysol of the experimental site was a wet soil with prolonged surface and perched water. The road drainage ditch was located near the tunnel. Soil quality, evaluated on a 100-point scale, ranged from 45 to 50 in the field, and 30 to 34 points in the tunnel. The contents of available P, K, Ca and Mg were determined by the ammonium lactate method (Egnér et al. 1960). The following soil nutrient values in the field were determined: $\mathrm{P}$ and $\mathrm{Mg}$ - excessive, $\mathrm{K}$ - high, $\mathrm{Ca}$ - medium and $\mathrm{pH}_{\mathrm{KCI}}$ was 5.4 (Table 1). $\mathrm{P}, \mathrm{K}, \mathrm{Ca}$, and $\mathrm{Mg}$ values in the tunnel were medium and $\mathrm{pH}_{\mathrm{KCl}}$ 5.6. No additional fertilizers were used in either experimental area.

Table 1. Nutrient content $\left(\mathrm{mg} \mathrm{kg}^{-1}\right)$ of the soil in two experimental areas

\begin{tabular}{lccccc}
\hline Treatment & $\mathrm{P}$ & $\mathrm{K}$ & $\mathrm{Mg}$ & $\mathrm{Ca}$ & $\mathrm{pH}_{\mathrm{KCl}}$ \\
\hline Field & 147 & 257 & 260 & 1670 & 5.4 \\
Tunnel & 22 & 170 & 98 & 830 & 5.6 \\
\hline
\end{tabular}

\section{Weather conditions}

In the field, the frost-free period was 150, 140 and 149 days in 2013, 2014 and 2015, respectively (Table 2). The last spring frost was on 29 April, 7 May and 10 May in 2013, 2014 and 2015, respectively. The first autumn frost was on 26 September, 24 September and 6 October in 2013, 2014 and 2015, respectively. In 2013, the warmest month was June, in 2014 - July, and in 2015 - August. The sum of active temperatures $\left(\geq 10^{\circ} \mathrm{C}\right)$ was $2490^{\circ} \mathrm{C}$ in $2013,2274{ }^{\circ} \mathrm{C}$ in 2014 and $2156^{\circ} \mathrm{C}$ in 2015 . The driest year was 2013 when precipitation from May to September was $269 \mathrm{~mm}$, and the wettest year was $2014(448 \mathrm{~mm})$, compared to 2015 (309 mm), with a yearly mean of 330 mm. In 2013 and 2014, the driest month was September, and in 2015, it was August.

In the tunnel area, the frost-free period was shorter than in the field (136 days) in 2013 and 2014, but longer (163 days) in 2015. The last spring frost was on 28 April, 1 May and 25 April in 2013, 2014 and 2015, respectively. The first autumn frost was recorded in the tunnel earlier than in the field for two experimental years. In the tunnel, June was the warmest month in 2013, while in 2014 and 2015 it was July (Table 2). In all experimental years, mean temperature and daily temperature fluctuations were higher in the tunnel than in the field, with differences larger between maximum than minimum temperatures, especially in the spring months (May, June), in 2013 and 2015 (the difference was 10.0 to $19.1^{\circ} \mathrm{C}$ ).

In 2013, 'Supaga' had no yield due to cold damage during winter in the field, hence the biochemical parameters in Table 3 are marked with "-". For the analysis, berries were harvested in 2013-2015. 
Table 2. Weather conditions in 2013-2015: monthly (mean, minimum and maximum) air temperature and total monthly precipitation sum compared to the mean of thirty years (1981-2010)

\begin{tabular}{|c|c|c|c|c|c|c|c|c|c|c|c|}
\hline \multirow[b]{3}{*}{ Year } & \multirow[b]{3}{*}{ Month } & \multicolumn{6}{|c|}{ Air temperature, ${ }^{\circ} \mathrm{C}$} & \multicolumn{4}{|c|}{ Precipitation, $\mathrm{mm}$} \\
\hline & & \multicolumn{3}{|c|}{ Open field } & \multicolumn{3}{|c|}{ Tunnel } & \multirow[b]{2}{*}{$\begin{array}{l}\text { Years } \\
\text { mean }\end{array}$} & \multirow[b]{2}{*}{ Site 1} & \multirow[b]{2}{*}{ Site 2} & \multirow[b]{2}{*}{$\begin{array}{l}\text { Years } \\
\text { mean }\end{array}$} \\
\hline & & Min & Max & Mean & Min & Max & Mean & & & & \\
\hline \multirow[t]{5}{*}{2013} & May & 3.7 & 28.1 & 15.5 & 4.2 & 38.1 & 20.4 & 10.4 & 73 & 45 & 42 \\
\hline & June & 6.9 & 29.8 & 17.8 & 7.4 & 40.1 & 21.6 & 14.4 & 35 & 31 & 69 \\
\hline & July & 8.4 & 28.7 & 17.5 & 8.3 & 37.5 & 21.1 & 17.4 & 59 & 43 & 72 \\
\hline & August & 4.7 & 31.8 & 16.6 & 5.8 & 36.1 & 18.9 & 16.3 & 79 & 85 & 83 \\
\hline & September & -0.9 & 21.9 & 10.8 & -2.3 & 27.5 & 12.8 & 11.5 & 23 & 55 & 64 \\
\hline \multirow[t]{5}{*}{2014} & May & -2.1 & 30.9 & 12.3 & -0.7 & 32.4 & 15.1 & 10.4 & 90 & 62 & 42 \\
\hline & June & 2.5 & 27.5 & 13.7 & 11.7 & 29.9 & 17 & 14.4 & 134 & 75 & 69 \\
\hline & July & 9.6 & 30.3 & 19.5 & 7.3 & 39.1 & 22.9 & 17.4 & 78 & 66 & 72 \\
\hline & August & 4.5 & 29.7 & 16.8 & 5.8 & 34.4 & 18.7 & 16.3 & 126 & 102 & 83 \\
\hline & September & -0.3 & 23.4 & 12.5 & -3.6 & 28.2 & 13.1 & 11.5 & 20 & 19 & 64 \\
\hline \multirow[t]{5}{*}{2015} & May & -0.8 & 20.4 & 10.6 & 0.6 & 38.2 & 16.5 & 10.4 & 61 & 33 & 42 \\
\hline & June & 3.7 & 24.6 & 14.6 & 4.2 & 43.7 & 19.6 & 14.4 & 66 & 58 & 69 \\
\hline & July & 6.9 & 27.2 & 16.1 & 8.4 & 38.8 & 20.3 & 17.4 & 68 & 67 & 72 \\
\hline & August & 3.6 & 30.7 & 17 & 5.4 & 40.3 & 19.3 & 16.3 & 47 & 25 & 83 \\
\hline & September & 3.1 & 23.1 & 12.8 & 1.7 & 29.7 & 14.4 & 11.5 & 67 & 97 & 64 \\
\hline
\end{tabular}

Site 1 = field; Site 2 = polytunnel. Temperature data were collected from an automatic weather station at the experimental sites. Sum of precipitation and many years mean monthly temperature and precipitation data were obtained from the Estonian Weather Station (www. ilmateenistus.ee) database

\section{Technological maturity parameters}

At harvest, the soluble solids content (SSC; ${ }^{\circ}$ Brix) was determined using a digital refractometer (Atago Pocket Refractometer Pal-1). 30 grapes from each of the three replications from different parts of clusters were analyzed. Additionally, the weight of ten randomly selected vine clusters was determined in each replication, and the number of berries per cluster was recorded. Berry weight was calculated from the data obtained.

$400 \mathrm{~g}$ of grapes from each of the three replications from the different parts of the cluster were analyzed. Titratable acid content (TAC) was determined by titration with $0.1 \mathrm{M} \mathrm{NaOH}$ solution to the endpoint of pH of 8.2 (Wrolstad et al. 2005) using a Mettler Toledo EasyPlus Titration titrator (with electrode DG 111-SC for endpoint detections). TAC was expressed in g of tartaric acid per $100 \mathrm{~g}$ fresh weight (FW). Soluble solids and titratable acidity ratio (SSC/ TAC) was calculated. Grape juice $\mathrm{pH}$ was measured with pH/conductivity-meter (HD 2156.1, Delta OHM). Maturity index (MI) was calculated according to the formula: $\mathrm{MI}={ }^{\circ} \mathrm{Brix} \times \mathrm{pH}^{2}$ (Coombe et al. 1980).

\section{Phenolic maturity parameters}

$400 \mathrm{~g}$ of grapes from each of the three replications from the different parts of the cluster were analyzed. The total phenolic content (TPC) of grape skin (exocarp of fruit) was determined by the Folin-Ciocalteu phenol reagent method (Wrolstad et al. 2005) with a spectrophotometer (UVmini-1240 Shimdzu) at $765 \mathrm{~nm}$. TPC was expressed in $\mathrm{mg}$ of gallic acid equivalent per $100 \mathrm{~g}$ of FW. Skin total anthocyanin content (ACC) was determined in cultivars 'Hasanski Sladki' and 'Zilga' using the $\mathrm{pH}$-differential method. Absorbance was measured with a spectrophotometer (Uvmini-1240 Shimdzu) at 510 and $700 \mathrm{~nm}$, in buffers with pH levels of $1.0(\mathrm{HCl} 0.1 \mathrm{~N}$ ) and 4.5 (citrate buffer). ACC was expressed in $\mathrm{mg}$ of cyanidin-3-glucoside equivalent per $100 \mathrm{~g}$ of FW.

\section{Statistical analysis}

The results were tested by one-way analysis of variance. To evaluate treatment effect within the cultivar, the least significant difference $\left(\mathrm{LSD}_{0.05}\right)$ was calculated, and different letters in the tables mark a significant difference at $p \leq 0.05$. To evaluate main effects of two factors (cultivation system and experimental year), two-way analysis of variance was carried out and the difference was marked as non-significant (ns) or, using confidence levels, as significant at $p \leq 0.05^{*}, 0.01^{* *}$ or $0.001^{* * *}$. Linear correlation coefficients were calculated between the variables 
( $\mathrm{n}=18$ 'Hasanski Sladki' and 'Zilga', $\mathrm{n}=15$ 'Supaga') with coefficient significance being $p \leq 0.05^{*}$, and $p \leq 0.01^{* *}$. Relationship strength was estimated as $r \leq 0.3$ (weak), $0.3 \leq r \leq 0.7$ (moderate), and $r \geq 0.7$ (strong).

\section{Results}

\section{Technological maturity}

The SSC of 'Supaga' varied among treatments in all experimental years ranging from 13.8 to $19.5^{\circ} \mathrm{Brix}$ (Table 3). There were significant differences between field and tunnel grown fruits. In 'Hasanski Sladki' and 'Zilga', SSC was from 15.1 to $25.4^{\circ}$ Brix and the difference was significant in two experimental years. In the tunnel, SSC increase ranged from 2 to $36 \%$ compared to the field. The main effect of treatment and year was significant at $p \leq 0.001$ for all cultivars.

Table 3. The effect of cultivation system on biochemical parameters and yield characteristics of 'Hasanski Sladki', 'Zilga' and 'Supaga' (2013-2015)

\begin{tabular}{|c|c|c|c|c|c|c|c|c|c|c|c|}
\hline Year & Treatment & SSC & TAC & $\begin{array}{l}\mathrm{SSC} / \\
\mathrm{TAC}\end{array}$ & $\mathrm{pH}$ & $\mathrm{MI}$ & TPC & $\mathrm{ACC}$ & $\begin{array}{c}\text { Berries/ } \\
\text { cluster, No }\end{array}$ & $\begin{array}{c}\text { Cluster } \\
\text { weight, g }\end{array}$ & $\begin{array}{c}\text { Berry } \\
\text { weight, g }\end{array}$ \\
\hline \multicolumn{12}{|c|}{ 'Hasanski Sladki' } \\
\hline \multirow[t]{2}{*}{2013} & Field & $21.8^{b}$ & $1.48^{a}$ & $14.8^{b}$ & $3.77^{\mathrm{a}}$ & $318^{a}$ & $326^{b}$ & $138^{b}$ & $59^{a}$ & $86^{a}$ & $1.47^{a}$ \\
\hline & Tunnel & $25.4^{\mathrm{a}}$ & $1.09^{b}$ & $23.3^{a}$ & $3.68^{a}$ & $344^{\mathrm{a}}$ & $480^{a}$ & $162^{a}$ & $39^{a}$ & $71^{a}$ & $1.80^{b}$ \\
\hline \multirow[t]{2}{*}{2014} & Field & $19.1^{\mathrm{a}}$ & $1.61^{a}$ & $11.9^{b}$ & $3.18^{b}$ & $194^{b}$ & $254^{b}$ & $30^{b}$ & $29^{b}$ & $27^{a}$ & $0.94^{a}$ \\
\hline & Tunnel & $19.5^{a}$ & $1.10^{b}$ & $17.7^{a}$ & $3.46^{a}$ & $233^{a}$ & $361^{a}$ & $48^{a}$ & $17^{a}$ & $43^{a}$ & $1.86^{b}$ \\
\hline \multirow[t]{2}{*}{2015} & Field & $17.5^{b}$ & $1.48^{a}$ & $11.8^{b}$ & $3.49^{b}$ & $213^{b}$ & $227^{b}$ & $51^{b}$ & $43^{a}$ & $48^{a}$ & $1.01^{a}$ \\
\hline & Tunnel & $21.8^{a}$ & $1.43^{a}$ & $14.7^{\mathrm{a}}$ & $3.60^{a}$ & $282^{a}$ & $274^{a}$ & $79^{a}$ & $41^{a}$ & $73^{a}$ & $1.70^{b}$ \\
\hline \multicolumn{2}{|l|}{ Year } & $* * *$ & $* * *$ & $* * *$ & $* * *$ & $* * *$ & $* * *$ & $* * *$ & $* * *$ & $* * *$ & $* * *$ \\
\hline \multicolumn{2}{|c|}{ Treatment } & $* * *$ & $* * *$ & $* * *$ & $* *$ & $* * *$ & $* * *$ & $* * *$ & $* *$ & ns & $* * *$ \\
\hline \multicolumn{12}{|l|}{ 'Zilga' } \\
\hline \multirow[t]{2}{*}{2013} & Field & $17.9^{b}$ & $1.58^{a}$ & $11.4^{\mathrm{b}}$ & $3.53^{b}$ & $223^{b}$ & $222^{b}$ & $64^{\mathrm{b}}$ & $96^{b}$ & $201^{a}$ & $2.45^{a}$ \\
\hline & Tunnel & $24.1^{a}$ & $1.19^{b}$ & $20.2^{a}$ & $3.60^{a}$ & $312^{a}$ & $540^{a}$ & $112^{\mathrm{a}}$ & $55^{a}$ & $189^{a}$ & $3.84^{b}$ \\
\hline \multirow[t]{2}{*}{2014} & Field & $15.1^{b}$ & $1.47^{a}$ & $10.3^{b}$ & $3.08^{b}$ & $143^{b}$ & $344^{a}$ & $32^{b}$ & $41^{a}$ & $48^{a}$ & $2.72^{a}$ \\
\hline & Tunnel & $20.5^{a}$ & $1.04^{b}$ & $19.7^{a}$ & $3.31^{a}$ & $225^{a}$ & $326^{b}$ & $125^{a}$ & $29^{a}$ & $102^{b}$ & $3.24^{b}$ \\
\hline \multirow[t]{2}{*}{2015} & Field & $15.3^{a}$ & $1.76^{\mathrm{a}}$ & $8.6^{b}$ & $3.34^{a}$ & $170^{b}$ & $273^{a}$ & $82^{a}$ & $42^{a}$ & $77^{a}$ & $1.88^{a}$ \\
\hline & Tunnel & $17.6^{a}$ & $1.58^{b}$ & $11.1^{a}$ & $3.35^{a}$ & $198^{a}$ & $256^{b}$ & $79^{a}$ & $58^{a}$ & $209^{b}$ & $3.23^{b}$ \\
\hline \multicolumn{2}{|l|}{ Year } & $* * *$ & $* * *$ & $* * *$ & $* * *$ & $* * *$ & $* * *$ & $* * *$ & $* * *$ & $* * *$ & $* * *$ \\
\hline \multicolumn{2}{|c|}{ Treatment } & $* * *$ & $* * *$ & $* * *$ & $* * *$ & $* * *$ & $* * *$ & $* * *$ & $*$ & $* * *$ & $* * *$ \\
\hline \multicolumn{12}{|c|}{ 'Supaga' } \\
\hline \multirow[t]{2}{*}{2013} & Field & - & - & - & - & - & - & $x$ & - & - & - \\
\hline & Tunnel & 18.8 & 1.30 & 14.5 & 3.47 & 227 & 100 & $x$ & 63 & 273 & 3.57 \\
\hline \multirow[t]{2}{*}{2014} & Field & $17.9^{b}$ & $1.47^{a}$ & $12.2^{b}$ & $3.07^{b}$ & $169^{a}$ & $74^{b}$ & $x$ & $35^{a}$ & $86^{a}$ & $2.49^{a}$ \\
\hline & Tunnel & $19.5^{a}$ & $1.11^{b}$ & $16.0^{a}$ & $3.36^{a}$ & $200^{a}$ & $104^{a}$ & $x$ & $59^{a}$ & $167^{b}$ & $3.06^{b}$ \\
\hline \multirow[t]{2}{*}{2015} & Field & $13.8^{b}$ & $1.67^{a}$ & $8.2^{b}$ & $3.15^{b}$ & $137^{b}$ & $228^{a}$ & $x$ & $68^{b}$ & $121^{a}$ & $1.82^{a}$ \\
\hline & Tunnel & $18.3^{a}$ & $1.13^{b}$ & $16.2^{a}$ & $3.59^{a}$ & $235^{a}$ & $53^{b}$ & $x$ & $40^{a}$ & $370^{b}$ & $3.52^{b}$ \\
\hline \multicolumn{2}{|l|}{ Year } & $* * *$ & $* *$ & $* *$ & $* * *$ & ns & $* * *$ & $x$ & ns & $* * *$ & ns \\
\hline \multicolumn{2}{|c|}{ Treatment } & $* * *$ & $* * *$ & $* * *$ & $* * *$ & $* * *$ & $* * *$ & $x$ & ns & $* * *$ & $* * *$ \\
\hline
\end{tabular}

$-=$ no yield $; x=$ no results; $\mathrm{SSC}=$ soluble solids content ( $\left.{ }^{\circ} \mathrm{Brix}\right) ; \mathrm{TAC}=$ titratable acid content $\left(\mathrm{g} 100 \mathrm{~g}{ }^{-1} \mathrm{FW}\right) ; \mathrm{SSC} / \mathrm{TAC}=$ soluble solids and

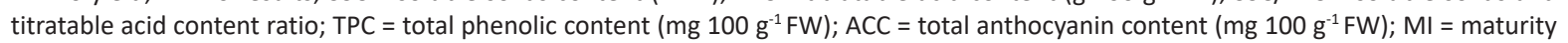
index. Different letters in the same columns among cultivar and year according to the site mark significant differences of means at $p \leq 0.05$. Main effect of treatment and year: $\mathrm{ns}, *, * *, * * *=$ non-significant or significant influence at $p \leq 0.05, p \leq 0.01$ or 0.001, respectively.

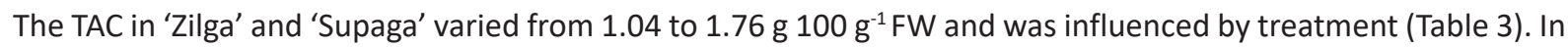

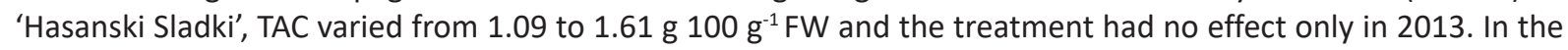
tunnel, TAC decrease ranged from 3 to $32 \%$. SSC/TAC was affected by the treatment and varied from 8.2 to 23.3. Thus in the field, SSC/TAC ratio decreased from 20 to $49 \%$. For all cultivars, the main effect of treatment and year on TAC and SSC/TAC were significant. 
The juice pH of 'Supaga' was significantly lower in the field and varied over the years from 3.07 to 3.59 (Table 3). For 'Zilga' and 'Hasanski Sladki' the same effect occurred in two years. In the field 'Zilga' pH varied between 3.08 to 3.53 and 'Hasanski Sladki' 3.18 to 3.77. In the tunnel 'Zilga' pH was between 3.31 to 3.60 and 'Hasanski Sladki' 3.46 to 3.68 . For all cultivars the main effect of treatment and year was significant.

The MI in 'Zilga' was significantly higher in the tunnel for all experimental years, whereas in 'Hasanski Sladki' and 'Supaga' the difference was not significant in one year (Table 3).The main effect of treatment and year was significant at $p \leq 0.001$ for 'Hasanski Sladki' and 'Zilga', but for 'Supaga' only treatment had a significant effect.

\section{Phenolic maturity}

The TPC differed significantly with treatment: in the tunnel, TPC of 'Hasanski Sladki' increased in all experimental years, while for 'Zilga' only in one year (Table 3). For 'Supaga' the TPC was positive in one year but negative in the other year. The ACC in 'Hasanski Sladki' grapes differed between field and tunnel in all experimental years and was significantly higher in the tunnel. In 'Zilga', the effect of treatment emerged in 2013 and 2014. The main effects of treatment and year on TPC and ACC were significant at $p \leq 0.001$.

\section{Yield characteristics}

The number of berries per cluster varied with cultivar: 'Hasanski Sladki' 17 to 59, 'Zilga' 29 to 96 and 'Supaga' 35 to 68 (Table 3). This variability was caused by year and all cultivars had a location effect in one year. In the tunnel 'Zilga' and 'Supaga' had significantly heavier cluster in 2014 and 2015. For all cultivars effect of year was significant. There was a significant effect of the treatment and experimental year on berry weight. In the tunnel, the grapes of all cultivars were heavier than those from the field.

\section{Correlations}

SSC and SSC/TAC in all cultivars had a strong positive correlation with berry weight (Table 4). TAC, on the other hand, had a strong negative correlation with berry weight. The juice $\mathrm{pH}$ in 'Hasanski Sladki' correlated positively with all berry parameters, in 'Zilga' - with berries per cluster and cluster weight (moderate and strong, respectively) and in 'Supaga' - with cluster weight and berry weight (both strong). In all cultivars, MI correlated positively with cluster weight and berry weight for 'Hasanski Sladki' and 'Supaga' both strong, for 'Zilga' - cluster weight moderate and berry weight strong. TPC correlated with berry weight - 'Hasanski Sladki' had a strong positive correlation, 'Zilga' had a moderately positive correlation, but 'Supaga' had a strong negative correlation. In 'Hasanski Sladki', ACC correlated positively with all berry parameters: for berries per cluster and berry weight moderate and for cluster weight strong. In 'Zilga', ACC had a positive correlation only with berry weight (moderate).

Table 4. The correlation coefficients between cluster characteristics and berry biochemical parameters of grapevine cultivars 'Hasanski Sladki', 'Zilga' and 'Supaga'

\begin{tabular}{|c|c|c|c|c|c|c|c|}
\hline Parameters & SSC & TAC & SSC/TAC & $\mathrm{pH}$ & $\mathrm{MI}$ & TPC & $\mathrm{ACC}$ \\
\hline \multicolumn{8}{|l|}{ 'Hasanski Sladki' } \\
\hline Berries/cluster & $0.265^{\mathrm{ns}}$ & $0.324^{\mathrm{ns}}$ & $-0.076^{\text {ns }}$ & $0.617^{* *}$ & $0.462 \mathrm{~ns}$ & $-0.067^{\mathrm{ns}}$ & $0.524 *$ \\
\hline Cluster weight, g & $0.629 * *$ & $-0.136^{\mathrm{ns}}$ & $0.382^{\text {ns }}$ & $0.875^{* *}$ & $0.801 * *$ & $0.341^{\mathrm{ns}}$ & $0.739 * *$ \\
\hline Berry weight, g & $0.668 * *$ & $-0.773 * *$ & $0.797 * *$ & $0.542 *$ & $0.660 * *$ & $0.733 * *$ & $0.503 *$ \\
\hline \multicolumn{8}{|l|}{ 'Zilga' } \\
\hline Berries/cluster & $0.069^{\text {ns }}$ & $0.337^{\text {ns }}$ & $-0.187^{\text {ns }}$ & $0.588^{*}$ & $0.257^{\mathrm{ns}}$ & $-0.273^{\mathrm{ns}}$ & $-0.070^{\mathrm{ns}}$ \\
\hline Cluster weight, g & $0.465^{\text {ns }}$ & $0.023^{\text {ns }}$ & $0.175^{\text {ns }}$ & $0.743 * *$ & $0.599 * *$ & $-0.073^{\mathrm{ns}}$ & $0.197^{\mathrm{ns}}$ \\
\hline Berry weight, g & $0.774 * *$ & $-0.699 * *$ & $0.760 * *$ & $0.305^{\mathrm{ns}}$ & $0.668 * *$ & $0.509 *$ & $0.498 *$ \\
\hline \multicolumn{8}{|l|}{ 'Supaga' } \\
\hline Berries/cluster & -0.199 ns & $-0.040^{\mathrm{ns}}$ & $-0.027^{\text {ns }}$ & $0.102^{\text {ns }}$ & $-0.040^{\text {ns }}$ & $0.388^{\text {ns }}$ & $x$ \\
\hline Cluster weight, g & $0.467^{\text {ns }}$ & $-0.702 * *$ & $0.690 * *$ & $0.888 * *$ & $0.799 * *$ & $-0.452^{\text {ns }}$ & $x$ \\
\hline Berry weight, g & $0.857 * *$ & $-0.835 * *$ & $0.891 * *$ & $0.858 * *$ & $0.975 * *$ & $-0.757 * *$ & $x$ \\
\hline
\end{tabular}

$\mathrm{x}=$ no results; SSC $=$ soluble solids content $\left({ }^{\circ} \mathrm{Brix}\right) ; \mathrm{TAC}=$ titratable acid content $\left(\mathrm{g} 100 \mathrm{~g}^{-1} \mathrm{FW}\right) ; \mathrm{SSC} / \mathrm{TAC}=$ soluble solids and titratable acid

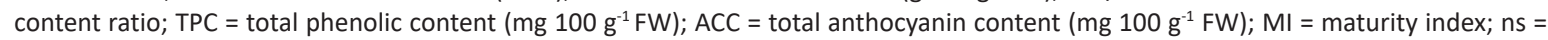
correlation coefficients between variables with the significance coefficient being non-significant, significant at $p \leq 0.05 *$ or $0.01 * *$ 


\section{Discussion}

In wine making, recommended values for berry technological maturity are used (van Schalkwyk and Archer 2000). The recommended ${ }^{\circ} \mathrm{Brix}$ in grapes for red wines is from 20.5 to 23.5 , and for white wines - from 19.5 to 23 . Hybrid cultivars in the current experiment were labrusca type, and for this kind of grape, the optimum can range from 17 to $18^{\circ}$ Brix (Plocher and Parke 2008). 'Hasanski Sladki' achieved the optimum (17-18 'Brix) level or above it in both experimental sites in all three years. In all experimental years, 'Zilga' and 'Supaga' reached the optimum level of ${ }^{\circ} \mathrm{Brix}$ in the tunnel, but not in all years in the field. The recommended TAC value should range from 0.65 to

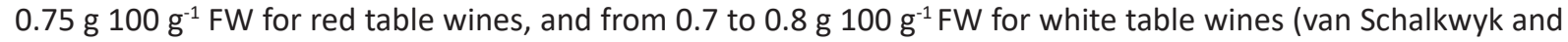
Archer 2000). In the tunnel, TAC was lower, but it was still significantly higher than the recommended level in all experimental cultivars. The recommended juice $\mathrm{pH}$ for white table wine is between 3.0 and 3.3, and for red table wine between 3.2 and 3.4. The recommended level was achieved by 'Zilga' in tunnel and field in 2014 and 2015 , by 'Supaga' in tunnel and field in 2014 and by 'Hasanski Sladki' in the field only and only in 2014.

The growing of grapes in the tunnel significantly affected their technological maturity parameters: for all cultivars in most cases, SSC and juice pH were significantly higher and TAC lower in the tunnel. According to Tarara et al. (2008), higher temperatures during ripening decrease TAC and increase juice $\mathrm{pH}$. Higher temperatures could have also affected TAC and juice $\mathrm{pH}$ in the current study. In test sites, there were significant differences in air temperatures. In the tunnel, the mean temperature in May was 4.9, 2.8 and $5.9^{\circ} \mathrm{C}$ higher $(2013,2014$ and 2015 , respectively) than in the field, and caused earlier growth of vines. In grapes, acids are formed during the first growth period (Kennedy 2002). Our results indicated that higher temperatures in the tunnel ( 3 to $5{ }^{\circ} \mathrm{C}$ in June and 3 to 4 ${ }^{\circ} \mathrm{C}$ in July) reduced the concentration of acid. The temperature was also higher during the period of veraison in August and September. During that period, higher temperature and greater daily temperature fluctuation influenced soluble solids and caused the reduction of acid levels. Tunnel monthly minimum and maximum temperatures differed almost by $30{ }^{\circ} \mathrm{C}$. The recommended MI level ranges from 200 to 270 (van Schalkwyk and Archer 2000). In the tunnel, MI reached the recommended level, and the results were influenced by higher SSC and juice $\mathrm{pH}$ values. Correlation results indicate that, cluster characteristics had a relationship with berry composition. All maturity parameters had a correlation with berry weight. In heavier berries, the SSC was higher and acid content lower. In cold climate conditions, the effect of vineyard location is important, and therefore, growers need to choose the warmest possible growing sites or use other methods, like tunnel cultivation.

There was a significant effect of cultivation system and location on phenolic maturity. Differences in experimental results were affected by vineyard location conditions, climate factors and cultivar properties. The soil of the two experimental areas differed - that in the field was more fertile than that in the tunnel. The impact of site on the test results was related to the soil and is consistent with previous experiments. Lower phenolic content of grapes is caused by more fertile vineyard soil (de Andrés-de Prado et al. 2007), and a decrease in polyphenol content with a higher nitrogen supply (Heimler et al. 2017). The growth habit of the experimental cultivars differed - 'Hasanski Sladki' is more vigorous than 'Zilga'. More vigorous growth and a longer plant growth period affects maturation and TPC and ACC values. Accumulation of phenolic compounds in grape skin is influenced by environmental factors (Soubeyrand et al. 2014), depends on cultivar (Katalini et al. 2010, Samoticha et al. 2017) and is highly influenced by terroir (Tarko et al. 2010). In the tunnel, the temperature was higher during the period of veraison in August (1.9 to $2.3^{\circ} \mathrm{C}$ ) and September $\left(0.6\right.$ to $2{ }^{\circ} \mathrm{C}$ ) than in the field. During this period, higher temperature and greater night and day temperature fluctuation influenced total phenol and anthocyanin accumulation. In the tunnel, monthly maximum temperatures were always higher than in the field. Day and night temperature fluctuation was also greater. For example, in 2015, in August, day and night temperature differences varied from 17.0 to $27.0^{\circ} \mathrm{C}$ in the tunnel, but from 4.3 to $18.8^{\circ} \mathrm{C}$ in the field.

Correlation analyses indicate that cluster characteristics had a relationship with phenolic maturity. For all cultivars TPC had a relationship with berry weight. 'Hasanski Sladki' ACC had positive correlation with all cluster characteristics, but for 'Zilga' only with berry weight. The effect of temperatures and sun exposure on anthocyanins depended on cluster distinctness - in thinner clusters, grapes are better exposed to light than in tighter clusters. 'Hasanski Sladki' clusters are thinner and, therefore the grapes are more exposed to sun and temperature fluctuation impact may have been bigger than in 'Zilga' with its denser and larger clusters. Cluster and berry weights can be affected by growing conditions. The differences in growing conditions between the tunnel and the field could have caused variation in compound bud vitality: whether shoots developed from a larger central primary bud, from smaller secondary buds, or from both at the same time. In the field, the growing season is shorter, and therefore, the vine primary bud may remain less cold hardy. When the primary bud is damaged, the smaller secondary or tertiary bud will break, which will greatly affect yield formation. 


\section{Conclusion}

Until now, in Estonia, table grape cultivars have been cultivated in tunnels and wine cultivars in the field. Our results support the hypothesis that in cold northern climate conditions, different vineyard cultivation systems affect the maturity of hybrid grapevines. In the tunnel, grapes had better technological maturity parameters - SSC increased and TAC decreased. On phenolic maturity, the treatment effect was significant and depended on the year and cultivar properties. Thus, for technological maturity enhancement, cultivation in polytunnels is recommended. The results confirmed the need for further research on special cultivars and cultivation methods in Estonia to explore the quality potential of grapes for winemaking.

\section{Acknowledgment}

This research was supported by Estonian Science Foundation Grant No. 9363, "Targeted Funding" project SF0170057s09 and Institutional Research Funding project IUT36-2.

\section{References}

Anesi, A., Stocchero, M., Dal Santo, S., Commisso, M., Zenoni, S., Ceoldo, S., Tornielli, G.B., Siebert, T.E., Herderich, M., Pezzotti, M. \& Guzzo, F. 2015. Towards a scientific interpretation of the terroir concept: plasticity of the grape berry metabolome. BMC Plant Biology 15: 191. https://doi.org/10.1186/s12870-015-0584-4

Baseline report 2017. Baseline report for the 4 main EU Climate Risk Regions 2017. https://agriadapt.eu/documents/. Accessed 1 March 2018.

Cheng, G., He, Y.N., Yue, T.X., Wang, J. \& Zhang, Z.W. 2014. Effects of Climatic Conditions and Soil Properties on Cabernet Sauvignon Berry Growth and Anthocyanin Profiles. Molecules 19: 13683-13703. https://doi.org/10.3390/molecules190913683

Coombe, B.G., Dundon, R.J. \& Short, A.W.S. 1980. Indices of sugar-acidity as ripeness criteria for wine grapes. Journal of the Science of Food and Agriculture 3: 495-502. https://doi.org/10.1002/jsfa.2740310512

de Andrés-de Prado, R., Yuste-Rojas, M., Sort, X., Andrés-Lacueva, C., Torres, M. \& Lamuela-Raventós, R.M. 2007. Effect of soil type on wines produced from Vitis vinifera L. cv. Grenache in commercial vineyards. Journal of Agricultural and Food Chemistry 55: 779-786. https://doi.org/10.1021/jf062446q

Deloire, A., Vaudour, M.E., Carey, V., Bonnardot, V. \& van Leeuwen, V. 2005. Grapevine responses to terroir: a global approach. Journal international des sciences de la vigne et du vin 39: 149-162. https://doi.org/10.20870/oeno-one.2005.39.4.888

Edo-Roca, M., Nadal, M. \& Lampreave, M. 2013. How terroir affects bunch uniformity, ripening and berry composition in Vitis vinifera cvs. Carignan and Grenache. Journal international des sciences de la vigne et du vin 47: 1-20. https://doi.org/10.20870/ oeno-one.2013.47.1.1533

Egnér, H., Riehm, H. \& Domingo, W.R. 1960. Untersuchungen uber die chemische Bodenanalyse als Grundlage fur die Beurteilung des Nährstoffzustandes der Böden. II. Chemische Extraktionsmethoden zur Phosphor- und Kaliumbestimmung. Kungliga Lantbrukshögskolans Annaler 26: 199-215.

Gustafsson, J.-G. \& Mårtensson, A. 2005. Potential for extending Scandinavian wine cultivation. Acta Agriculturae Scandinavica, Section B - Soil \& Plant Science 55: 82-97. https://doi.org/10.1080/09064710510029097

Heimler, D., Romani, A. \& Leri, F. 2017. Plant polyphenol content, soil fertilization and agricultural management: a review. European Food Research and Technology, 243: 1107-1115. https://doi.org/10.1007/s00217-016-2826-6

Hunter, J.J. \& Deloire, A. 2006. Terroir and vine water relation effects on grape ripening and wine quality of Syrah/R99. Proceedings of the 4th International terroir congress, 3-7 July in Bordeaux and Montpellier, France. p. 110-116.

Jones, G.V., White, M.A., Cooper, O.R. \& Storchmann, K. 2005. Climate change and global wine quality. Climate Change 73: 319343. https://doi.org/10.1007/s10584-005-4704-2

Kamiloğlu, Ö., Polat, A.A. \& Durgaç, C. 2011. Comparison of open field and protected cultivation of five early table grape cultivars under Mediterranean conditions. Turkish Journal of Agriculture and Forestry 35:491-499. https://doi.org/10.3906/tar-1002-718

Karvonen, J. 2014a. The annual growth cycle of grapevines in Southern Finland. Vitis 54: 175-180.

Karvonen, J. 2014b. Vitis cv. Zilga is a vine for the northern temperate climate - Short communication. Horticultural Science (Prague) 41: 147-151. https://doi.org/10.17221/17/2014-HORTSCI

Katalini, V., Moina, S.S., Skroza, D., Generali, I., Abramovi, H., Milo, M., Ljubenkov, I., Piskernik, S., Pezo, I., Terpinc, P. \& Boban, M. 2010. Polyphenolic profile, antioxidant properties and antimicrobial activity of grape skin extracts of 14 Vitis vinifera varieties grown in Dalmatia (Croatia). Food Chemistry 119: 715-723. https://doi.org/10.1016/j.foodchem.2009.07.019

Kennedy, J. 2002. Understanding grape berry development. Practical Winery \& Vineyard 1-5.

Keskin, N., İşçi, B. \& Gökbayrak, Z. 2013. Effect of cane-girdling and cluster and berry thinning on berry organic acids of four Vitis vinifera $\mathrm{L}$ table grape cultivar. Acta Scientiarum Polonorum Hortorum Cultus 12: 115-125.

Lisek, J. 2012. Winter frost injury of buds on one-year-old grapevine shoots of Vitis vinifera cultivars and interspecific hybrids in Poland. Folia Horticulturae 24: 97-103. https://doi.org/10.2478/v10245-012-0010-4

Maante, M., Vool, E. \& Karp, K. 2016. Effect of defoliation on grape maturity parameters. Sodininkyste ir Darzininkyste 35: 21-35. 
Nordmark, L., Lindén, J., Skjöldebrand, C. \& Hansson, H. 2016. The Nordic Light Terroir. Acta horticulturae 1115: 189-194. https:// doi.org/10.17660/ActaHortic.2016.1115.28

Pedastsaar, P., Vaher, M., Kulp, M., Kaljurand, M., Karp, K., Raal, A., Karathanos, V. \& Püssa, T. 2014. Chemical composition of red wines made from hybrid grape and common grape (Vitis vinifera L.) cultivars. Proceedings of the Estonian Academy of Sciences 63: 444-453. https://doi.org/10.3176/proc.2014.4.10

Pereira, G.E., Gaudillere, J.P., van Leeuwen, C., Hilbert, G., Maucourt, M. \& Deborde, C. 2006. H1-NMR metabolite fingerprints of grape berry: Comparison of vintage and soil effects in Bordeaux grapevine growing areas. Analytica Chimica Acta 563: 346-352. https://doi.org/10.1016/j.aca.2005.11.007

Plocher, T. \& Parke, B. 2008. Northern Wineworks: growing grapes and making wine in cold climates, 2th Ed. Northern Winework Inc., Hugo, Minnesota. 214 p.

Rätsep, R., Karp, K., Vool, E. \& Tõnutare, T. 2014. Effect of pruning time and method on hybrid grapevine (Vitis sp.) 'Hasanski Sladki' berry maturity in a cool climate conditions. Acta Scientiarum Polonorum Hortorum Cultus 13: 99-112.

Samoticha, J., Wojdyło, A. \& Golis, T. 2017. Phenolic composition, physicochemical properties and antioxidant activity of interspecific hybrids of grapes growing in Poland. Food Chemistry 215: 263-273. https://doi.org/10.1016/j.foodchem.2016.07.147

Soubeyrand, E., Basteau, C., Hilbert, G., van Leeuwen, C., Delrot, S. \& Gomès, E. 2014. Nitrogen supply affects anthocyanin biosynthetic and regulatory genes in grapevine cv. Cabernet-Sauvignon berries. Phytochemistry 103: 38-49. https://doi.org/10.1016/j. phytochem.2014.03.024

Tarara, M.J., Lee, J., Spayd, E.S. \& Scagel, F.C. 2008. Berry temperature and Solar Radiation alter acylation, propotion, and concentration of anthocyanin in Merlot grapes. American Journal of Enology and Viticulture 59: 235-247.

Tarko, T., Duda-Chodak, A., Sroka, P., Satora, P. \& Jurasz, E. 2010. Polish wines: characteristics of cool-climate wines. Journal of Food Composition and Analysis 23: 463-468. https://doi.org/10.1016/j.jfca.2010.01.009

Tarricone, L., Masi, G., Amendolagine, A., Di Gennaro, D., Suriano, S., Savino, M., Bavaresco, L. \& Gardiman, M. 2013. Terroir influence on viticultural and oenological characteristics of Vitis vinifera cv. Negro Amaro. Proceedings of the 36th World Congress of vine and wine, in 2-7 June in Bucharest, Romania. http://hdl.handle.net/10807/61704

van Leeuwen, C. \& Seguin, G. 2006. The concept of terroir in viticulture. Journal of Wine Research 17: 1-10. https://doi. org/10.1080/09571260600633135

van Schalkwyk, H. \& Archer, E. 2000. Determining optimum ripeness in wine grapes. Wineland 130: 90-91.

Wrolstad, R.E., Acree, T.E., Decker, E.A., Penner, M.H., Reid, D.S., Schwartz, S.J., Shoemaker, C.F., Denise, M.S. \& Sporns, P. 2005. Handbook of Food Analytical Chemistry. Pigments, colorants, flavors, texture, and bioactive food components. New Jersey: John Wiley \& Sons. 624 p. https://doi.org/10.1002/0471709085 